\title{
Characterization of a Brome mosaic virus Strain and Its Use as a Vector for Gene Silencing in Monocotyledonous Hosts
}

\author{
Xin Shun Ding, William L. Schneider, Srinivasa Rao Chaluvadi, M. A. Rouf Mian, and Richard S. Nelson \\ Samuel Roberts Noble Foundation, Inc., 2510 Sam Noble Parkway, Ardmore, OK, 73401, U.S.A. \\ Submitted 2 March 2006. Accepted 19 June 2006.
}

\begin{abstract}
Virus-induced gene silencing (VIGS) is used to analyze gene function in dicotyledonous plants but less so in monocotyledonous plants (particularly rice and corn), partially due to the limited number of virus expression vectors available. Here, we report the cloning and modification for VIGS of a virus from Festuca arundinacea Schreb. (tall fescue) that caused systemic mosaic symptoms on barley, rice, and a specific cultivar of maize (Va35) under greenhouse conditions. Through sequencing, the virus was determined to be a strain of Brome mosaic virus (BMV). The virus was named F-BMV (F for Festuca), and genetic determinants that controlled the systemic infection of rice were mapped to RNAs 1 and 2 of the tripartite genome. cDNA from RNA 3 of the Russian strain of BMV (R-BMV) was modified to accept inserts from foreign genes. Coinoculation of RNAs 1 and 2 from F-BMV and RNA 3 from R-BMV expressing a portion of a plant gene to leaves of barley, rice, and maize plants resulted in visual silencing-like phenotypes. The visual phenotypes were correlated with decreased target host transcript levels in the corresponding leaves. The VIGS visual phenotype varied from maintained during silencing of actin 1 transcript expression to transient with incomplete penetration through affected tissue during silencing of phytoene desaturase expression. F-BMV RNA 3 was modified to allow greater accumulation of virus while minimizing virus pathogenicity. The modified vector $\mathrm{C}-\mathrm{BMV}_{\mathrm{A} / \mathrm{G}}(\mathrm{C}$ for chimeric) was shown to be useful for VIGS. These BMV vectors will be useful for analysis of gene function in rice and maize for which no VIGS system is reported.
\end{abstract}

Additional keywords: functional genomics, Oryza sativa, RNA silencing, Zea mays.

RNA silencing, encompassing RNA interference (RNAi) in insects and mammals, post-transcriptional gene silencing in plants, and quelling in fungi, has captured the interest of plant

Corresponding author: R. S. Nelson; Telephone: +1.580 .224 .6625 ; Fax: +1.580.224.6692; E-mail: rsnelson@ noble.org

Current address of W. L. Schneider: USDA-ARS, 1301 Ditto Ave., Fort Detrick, MD 21702, U.S.A.

Current address of M. A. Rouf Mian: USDA-ARS \& HCS, Ohio State University, 1680 Madison Avenue, Wooster, Ohio 44691, U.S.A.

Nucleotide sequence data is available in the GenBank database under accession numbers DQ530423, DQ530424, and DQ530425 for clones $\mathrm{pF} 1-11, \mathrm{pF} 2-2$, and $\mathrm{pF} 3-5$. molecular biologists and pathologists. RNAi pathways in various organisms differ in particular steps, but all function to destroy RNA in a sequence-specific manner (e.g., Mello and Conte 2004). Virus infection of plants can also induce RNA silencing and is referred to as virus-induced gene silencing (VIGS) (Al-Kaff et al. 1998; Covey et al. 1997; Ratcliff et al. 1997). Reports from several research groups have demonstrated that plant viruses can be modified to express portions of host genes with known or unknown function that are then targeted for silencing (Burch-Smith et al. 2004; Lu et al. 2003a). Doublestranded (ds)RNA, produced during the replication of modified viruses in infected cells or present within segments of the single-stranded RNA genome (i.e., as inverted repeats) are considered to be the trigger for VIGS (Smith et al. 2000; Voinnet 2005; Waterhouse et al. 1998). Virally encoded dsRNA in cells is recognized by either a host RNA-dependent RNA polymerase, which extends the dsRNA sequence, or directly by a dsRNA-specific Rnase III-type endonuclease (Dicer-like) that processes the dsRNA into small interfering (si)RNAs of approximately 21 to 25 nucleotides (Baulcombe 2004; Meister and Tuschl 2004). Single strands of the ds-siRNAs, complementary to the target RNA, program the RNA-induced silencing complex and guide it to the target RNA (Meister and Tuschl 2004). The destruction of target mRNA due to VIGS sometimes results in a visible phenotype in the infected plants, allowing a rapid method to decipher the function of a target gene (Burch-Smith et al. 2004; Lu et al. 2003a). Because VIGS is a rapid procedure and does not require development of stable transformants, it also has been used in large-scale forward genetic screens in Nicotiana benthamiana (Lu et al. 2003b; Slaymaker et al. 2002).

Many viruses, including Bean pod mottle virus, Pea early browning virus, Potato virus $X$, Tobacco mosaic virus (TMV), Tobacco rattle virus (TRV), Tomato bushy stunt virus, Tomato golden mosaic virus, and a viral satellite DNA (DNA $\beta$ ) associated with Tomato yellow leaf curl China virus have been used as vectors for VIGS in dicotyledonous plants (Burch-Smith et al. 2004; Constantin et al. 2004; Fu et al. 2005; Kjemtrup et al. 1998; Kumagai et al. 1995; Liu et al. 2002; Qiu et al. 2002; Ratcliff et al. 2001; Ruiz et al. 1998; Tao and Zhou 2004; Zhang and Ghabrial 2006). However, VIGS in monocotyledons has been limited to only one virus, Barley stripe mosaic virus (BSMV) in two monocotyledonous hosts, Hordeum vulgare (barley) and Triticum aestivum (wheat) (Hein et al. 2005; Scofield et al. 2005; Tai et al. 2005). Additional viruses modified for use in VIGS are needed to compare the effectiveness of each in common hosts and for use in monocotyledonous crops such as Oryza sativa (rice) and Zea mays (maize), in which no VIGS vector has been reported. 
Brome mosaic virus (BMV) is a positive-strand tripartite RNA virus and is the type member of the genus Bromovirus. The BMV genome consists of three RNA segments known as RNA 1, RNA 2, and RNA 3 (Ahlquist 1999). RNA 1 and RNA 2 encode nonstructural proteins (1a and $2 \mathrm{a}$ ) necessary for BMV replication (Kao and Ahlquist 1992; Kiberstis et al. 1981; Kroner et al. 1989, 1990; Quadt and Jaspars 1990). RNA 3 encodes a movement protein (MP) required for BMV cell-tocell movement and a coat protein $(\mathrm{CP})$ required for virion formation and host-specific cell-to-cell movement (Ahlquist et al. 1981; Dasgupta and Kaesberg 1982; Rao and Grantham 1996; Flasinski et al. 1995; Sacher and Ahlquist 1989; Takeda et al. 2005). BMV is present in many countries around the world, has one of the broadest monocotyledon host ranges among viruses, and remains at high levels in cells of infected plants over time (Lane 1981). For many years, BMV has been a useful model for studies of positive-strand RNA virus replication, movement, recombination, virion formation, and other processes, all often involving interaction with host factors (Kao and Sivakumaran 2000; Noueiry and Ahlquist 2003). Recently, we identified a virus from a tall fescue plant (Festuca arundinacea Schreb.) with characteristics similar to BMV (Rouf Mian et al. 2005). Here, we report its further characterization, cloning, and modification to serve as a VIGS vector in barley, rice, and maize plants.

\section{RESULTS}

\section{Isolation and host range analysis of the fescue strain of BMV (F-BMV).}

Breeding stock of tall fescue showing mosaic leaves, stunted growth, and low vigor was determined to contain a virus with characteristics similar to BMV (Rouf Mian et al. 2005). This virus isolate was referred to as F-BMV. Inoculation of purified F-BMV virion to tall fescue plants resulted in a systemic chlorotic mosaic similar to that observed on the original breeding stock (Fig. 1A) (Rouf Mian et al. 2005). Like the Russian strain of BMV (R-BMV), F-BMV caused systemic infection in barley, maize, and many other monocotyledons. Symptoms on these plants, however, were milder than those caused by RBMV (compare images in Fig. 1B; data not shown). Interestingly, under our greenhouse conditions, F-BMV but not RBMV induced a systemic infection in all rice cultivars and plant introductions (PI) tested, based on visual observation and presence of viral RNA (Fig. 1C and D). The systemic symptoms displayed by F-BMV-infected rice plants were often chlorotic streaks in leaves by 10 days postinoculation (dpi), followed by slightly stunted growth (Fig. 1C and data not shown).

\section{Virus cloning and sequencing.}

To further characterize F-BMV, multiple cDNA clones representing F-BMV RNAs 1, 2, and 3 were sequenced. There were 32, 60, and 19 nucleotide substitutions, respectively, in consensus sequences representing RNAs 1, 2, and 3 of F-BMV as compared with the corresponding sequences of R-BMV (Ahlquist, et al. 1981, 1984). The sequences representing RNAs 1, 2, and 3 of the F-BMV cDNA clones used to make infectious transcript (described below) were deposited in GenBank (accession numbers DQ530423, DQ530424, and DQ530425 for clones pF1-11, pF2-2, and pF3-5, respectively). These sequences differed from the consensus sequences for the genomic RNAs in a few positions (noted in the GenBank submission for each clone). Three cDNA clones representing RBMV RNAs 1, 2, and 3 (pB1-26, pB2-4, and pB3-3) were also prepared and sequenced as described for the F-BMV RNAs.

Seven of the 32 nucleotide substitutions in the F-BMV RNA1 sequence would result in amino-acid substitutions at positions 17 (Asp-Ala), 350 (Ser-Asn), 512 (Lys-Ile), 726 (TyrPhe), 803 (Gln-Lys), 859 (Gly-Val), and 914 (Thr-Ala) in the 1a protein. Eight of the 60 nucleotide substitutions in the F-BMV RNA 2 sequence would result in amino-acid substitutions at positions 324 (Asp-Glu), 381 (Cys-Arg), 609 (Val-Ile), 613 (Leu-Met), 655 (Thr-Met), 717 (Thr-Met), 746 (Ile-Leu), and 809 (Val-Leu) in the 2a protein. Amino-acid substitutions within the 2 a protein occurred unevenly and were located mainly toward the C-terminal portion of the protein. Within the RNA 3 sequence, two amino-acid substitutions were predicted in the MP at position 81 (Ser-Pro) and position 299 (Thr-Ser), and three amino-acid substitutions were predicted in the $\mathrm{CP}$ at positions 23 (Trp-Arg), 26 (Arg-Thr) and 35 (Leu-Phe). The total number of nucleotide substitutions, spread throughout RNAs 1,2 , and 3 , represented only $1.3 \%$ of the genome sequence, supporting the classification of this virus as a strain of BMV and not a new virus species.

\section{Infectivity of transcripts and genetic determinants within $F-B M V$ required for systemic infection of rice.}

The RNA transcripts from F-BMV and R-BMV clones were compared for infectivity by inoculating them to barley leaves. By 7 dpi, plants inoculated with F-BMV transcripts developed milder systemic mosaic symptoms followed by only slightly stunted growth, as compared with those inoculated with RBMV transcripts. Symptoms induced by F-BMV and R-BMV transcripts were similar to those induced by the parental viruses shown in Figure 1B. Inoculation of crude extracts from the FBMV-infected barley leaves to rice cv. IR8 and PI615210 resulted in a systemic infection in these plants by $10 \mathrm{dpi}$. The symptoms induced on these plants were similar to those induced by the parental F-BMV strain (data not shown). No symptoms were observed in rice plants inoculated with crude extracts from R-BMV-infected barley leaves (data not shown).

To determine which genomic segments of F-BMV were required to infect rice, RNA transcripts representing genomic RNAs 1,2 , and 3 of F-BMV or R-BMV were mixed (reassorted; i.e., FFF, FFR, FRF, FRR, RFR, RFF, RRF, and RRR), and the infectivity of the different combinations evaluated in rice after passage through Chenopodium quinoa and barley. Rice cv. IR8 and PI615210 plants inoculated with the reassorted viruses containing either one or both of RNAs 1 and 2 of FBMV (e.g., FFF, FFR, FRF, FRR, RFR, and RFF) or with FBMV developed systemic mosaic symptoms (data not shown). Through immunocapture reverse transcriptase-polymerase chain reaction (RT-PCR) assays, we determined that the percentage of infected plants inoculated with F-BMV or reassorted viruses containing either one or both of RNAs 1 and 2 from FBMV ranged from 37 to $100 \%$ for cv. IR 8 or PI615210 (Table 1). IR 8 and PI615210 plants inoculated with virus not containing either one or both of RNAs 1 and 2 from F-BMV (RRF and RRR) did not display systemic virus symptoms by 30 dpi and no virus was detected in their systemic leaves (Table 1 and data not shown). Results from this study indicate that, under our greenhouse conditions, F-BMV RNA 1 or 2 were required for the systemic infection in rice.

\section{Construction and use of a BMV vector for VIGS in barley, rice, and maize.}

We proceeded to modify our cDNA clones to facilitate their use as vectors, to study gene function through VIGS. Several unique restriction sites within the $\mathrm{pF} 3-5$ and $\mathrm{pB} 3-3$ constructs were chosen, and the vectors tested for maintenance of foreign gene inserts. A HindIII restriction site within the $3^{\prime}$ untranslated region of $\mathrm{pB} 3-3$ or $\mathrm{pF} 3-5$ was the only site that allowed continued expression of foreign gene fragments (Fig. 2A). Because RNA 1 or 2 of F-BMV was required for infection in rice and 
pF3-5, representing RNA 3 of F-BMV, contained two HindIII restriction sites (nucleotide positions 1,020 and 1,914), we initially chose to insert foreign sequences into the pB3-3 clone representing the R-BMV strain (only one HindIII restriction site present). To evaluate the potential of the hybrid vector representing RNAs 1 and 2 from F-BMV and RNA 3 from RBMV (referred to hereafter as H-BMV) for use in gene silencing, a 240-bp fragment from the maize phytoene desaturase (PDS) gene was inserted into the pB3-3 clone (pB3-3/PDS ${ }_{240}$ ).
Alignment of the maize PDS fragment sequence with PDS sequences from barley (GenBank accession number AY062039) and rice (GenBank accession number AF049356) showed high sequence identity (93\% between maize and barley and $91 \%$ between maize and rice). An 86-bp fragment was then amplified from within the 240-bp fragment and was cloned into the $\mathrm{pB} 3-3$ vector $\left(\mathrm{pB} 3-3 / \mathrm{PDS}_{86}\right)$. Transcripts representing $\mathrm{H}$ $\mathrm{BMV} \mathrm{PDS}_{86}$ and $\mathrm{H}-\mathrm{BMV} / \mathrm{PDS}_{240}$ were inoculated to leaves of barley. Transcripts representing H-BMV (i.e., without the PDS
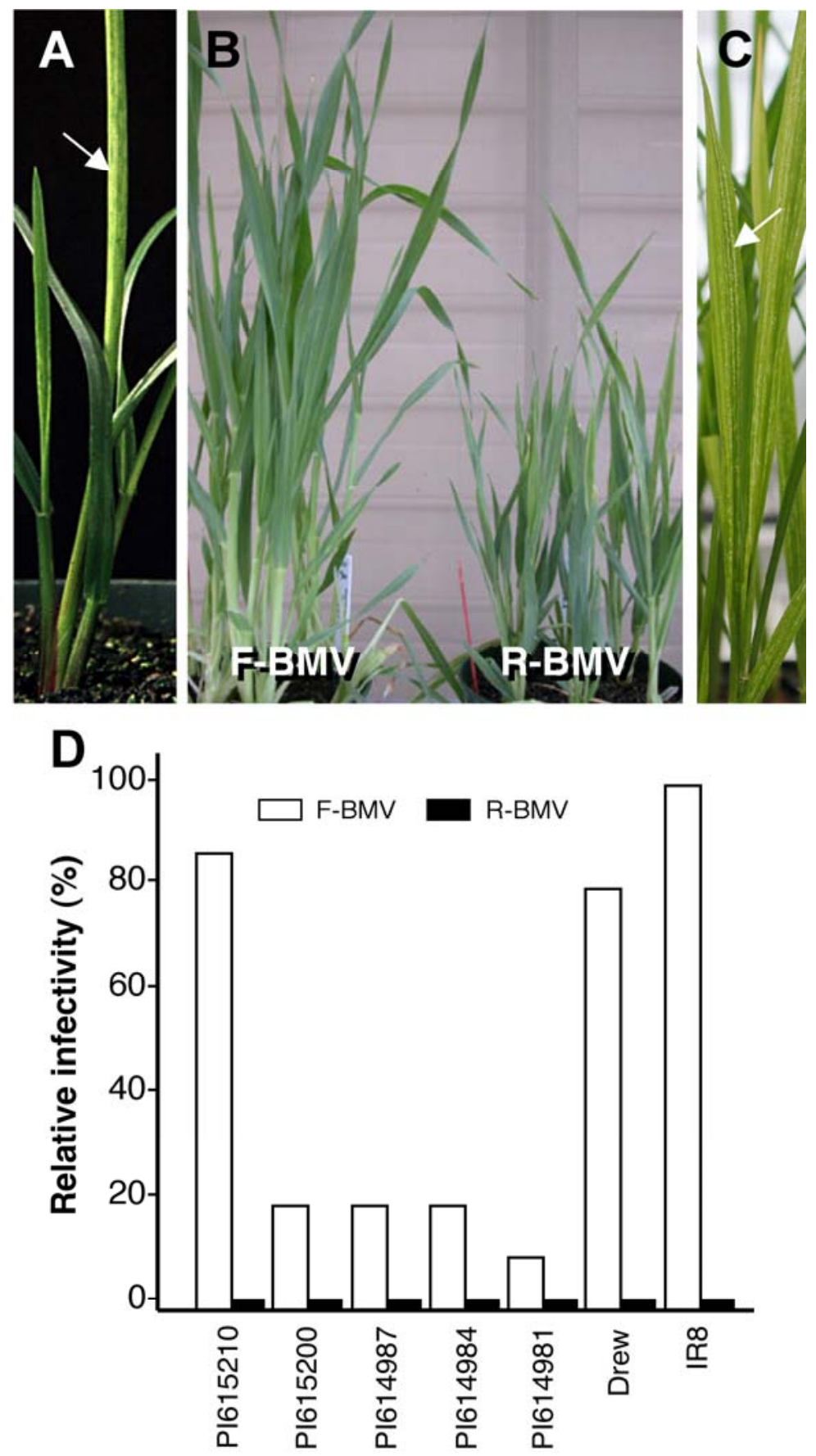

Fig. 1. Symptoms induced by the fescue strain of Brome mosaic virus (F-BMV) on tall fescue, barley, and rice plants and relative infectivity of F-BMV and the Russian strain of BMV (R-BMV) on rice cultivars and introductions. A, Tall fescue plant inoculated with F-BMV showing systemic chlorotic streaks (arrow) at 10 days postinoculation (dpi) on upper uninoculated (systemic) leaf. B, Barley plants (cv. Morex) infected with F-BMV and R-BMV at 28 dpi. Note that plants infected with R-BMV are smaller than plants infected with F-BMV. C, Rice plants (cv. IR8) inoculated with F-BMV showing systemic chlorotic streaks (arrow) in upper systemic leaves at 20 dpi. D, Percentage of plants infected after inoculation of two rice cultivars and five plant introductions (PI) with F-BMV or R-BMV. Seedlings were inoculated with virus at 12 days after planting. The inoculated plants were analyzed for virus infection through immunocapture reverse transcriptase-polymerase chain reaction at 28 dpi. Five plants per rice cultivar or PI were inoculated with each virus, and the experiment was repeated once with similar results. 
insert) were also inoculated to plants as a vector control. Plants inoculated with RNA transcripts representing $\mathrm{H}-\mathrm{BMV} / \mathrm{PDS}_{86}$ or H-BMV/PDS ${ }_{240}$ developed light-yellow and white streaks in the second leaf above the inoculated leaf by 10 dpi (Fig. 3A and data not shown). In later developing leaves, light-yellow and white streaks were also observed, but the number of streaks per leaf decreased with each succeeding leaf. Crude extracts from $\mathrm{H}-\mathrm{BMV} / \mathrm{PDS}_{86}$-infected barley leaves showing light-yellow and white streaks were inoculated to leaves of maize cv. Va35 and rice PI615210. By 10 dpi, white streaks in upper uninoculated maize leaves and, by 14 dpi, light-yellow and white streaks in upper uninoculated rice leaves were observed (Fig.3B and C). As for the infected barley plants, the number of light-yellow or white streaks on young leaves of maize and rice increased to a maximum on approximately the second systemically infected leaf and then decreased with each succeeding leaf. No extensive light-yellow or white streaking (bleaching) phenotype was observed in barley, rice, or maize leaves infected with H-BMV lacking the PDS insert. Thus, a bleaching phenotype indicative of the silencing of the host PDS gene was present in the plants infected with the $\mathrm{H}$ -

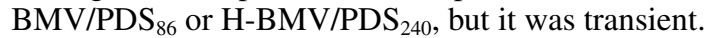

To provide further evidence that the PDS gene in plants showing bleaching symptoms was silenced through VIGS, total RNA was isolated from systemically infected leaves of maize plants inoculated with the $\mathrm{H}-\mathrm{BMV} / \mathrm{PDS}_{86}, \mathrm{H}-\mathrm{BMV}$, or phosphate buffer (PB) alone at various dpi and was subject to semiquantitative RT-PCR analysis, to determine the steadystate level of the target host mRNA. Maize and barley leaves showing bleaching symptoms contained less PDS mRNA than leaves infected with the H-BMV or leaves not infected with virus (Fig. 3D; data not shown). These results support the conclusion that BMV can be used as a vector to analyze gene function in barley, maize, and rice plants through VIGS-mediated gene knock-down technology.

To further test the suitability of H-BMV as a vector for VIGS, a 398-bp fragment from the rice actin 1 gene was inserted into pB3-3. Actin was targeted because we previously determined that downregulating actin levels in Nicotiana benthamiana through VIGS using a TRV vector resulted in a clear visual phenotype, stunted growth (Liu et al. 2005; data not shown). RNA transcripts representing H-BMV/Actin 398 were inoculated to leaves of $N$. benthamiana plants. At 12 dpi, systemically infected $N$. benthamiana leaves were harvested and crude extracts from these leaves were inoculated to rice cv. IR8. By 21 dpi, rice plants inoculated with H-BMV/Actin 398 developed stronger leaf mosaic symptoms and more stunting than those infected with H-BMV (Fig. 4A; data not shown). Quantitative RT-PCR analyses showed that the actin $1 \mathrm{mRNA}$ level in $\mathrm{H}-$ BMV/Actin 398 -infected plants was approximately 16 and $15 \%$, respectively, the level in plants inoculated with $\mathrm{H}-\mathrm{BMV}$ or $\mathrm{PB}$ (Fig. 4B). The quantitative RT-PCR results support the conclusion based on visual observations that the actin 1 gene in $\mathrm{H}$ BMV/Actin 398 -inoculated plants was silenced through VIGS.
Construction and use

of an improved VIGS vector, the chimeric $(C)-B M V_{A / G}$.

Like R-BMV, H-BMV caused some visual symptoms (stunted plant growth, chlorosis in affected leaves) that may interfere with the interpretation of results from VIGS studies. To search for a virus that would accumulate viral RNA to high levels while producing milder symptoms than those caused by $\mathrm{R}-\mathrm{BMV}$ and $\mathrm{H}-\mathrm{BMV}$, we modified the intergenic region (IR)
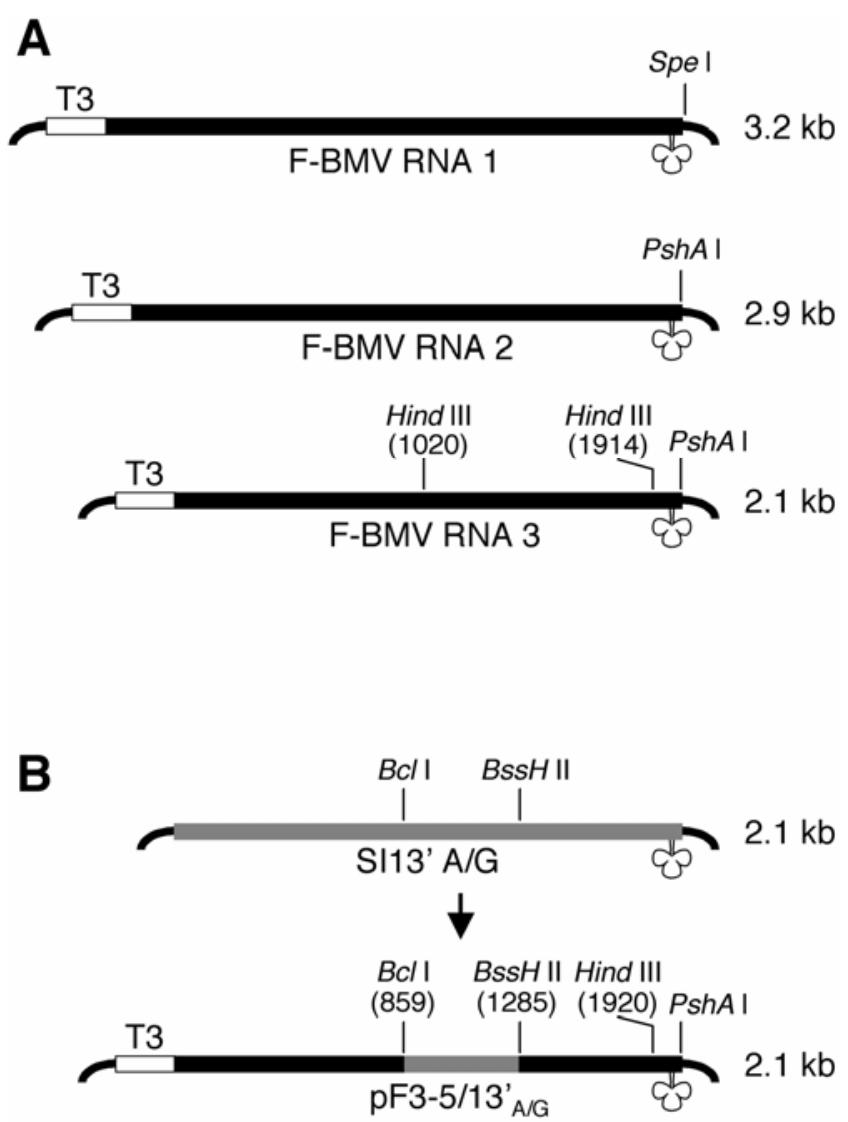

Fig. 2. Schematic representation of Brome mosaic virus (BMV) clones and sequence modification. A, Schematic of clones containing RNAs 1, 2, and 3 of the fescue strain of BMV (F-BMV). Black rectangles represent virus sequence. The curled lines at both sides of each construct represent bacterial plasmid sequence. The clover-like symbol represents the tRNAlike structure at the $3^{\prime}$ end of the virus sequence. PshAI and SpeI are restriction sites for plasmid linearization prior to in vitro transcription. T3 $=$ $\mathrm{T} 3$ promoter sequence (open rectangle) for in vitro transcription of viral sequences. B, Schematic showing the production of a modified F-BMV RNA 3 sequence for use in the chimeric (C)-BMV $\mathrm{B}_{\mathrm{A} / \mathrm{G}}$ vector. A Bcll/BssHII fragment was released from the cDNA sequence representing a modified R-BMV RNA 3 (SI13'A/G) and was inserted into the $B c l \mathrm{I} / B s s \mathrm{HII}$ restriction site within the cDNA representing F-BMV RNA 3. The resulting plasmid was designated $\mathrm{pF} 3-5 / 13^{\prime}{ }_{\mathrm{A} / \mathrm{G}}$ (synonym: $\mathrm{pC}-\mathrm{BMV} \mathrm{RNA} 3_{\mathrm{A} / \mathrm{G}}$ ). Gray rectangles represent cDNA of the modified R-BMV RNA 3.

Table 1. Identification of the viral genomic components necessary for the systemic infection of rice by the fescue strain of Brome mosaic virus (F-BMV) ${ }^{\mathrm{a}}$

\begin{tabular}{lllllllll}
\hline & \multicolumn{8}{c}{ Reassorted viruses } \\
\cline { 2 - 9 } Rice cultivar & FFF $^{\mathbf{b}}$ & FFR & FRF & RFF & FRR & RFR & RRF & RRR \\
\hline PI615210 & $16 / 16^{\mathbf{c}}$ & $11 / 16$ & $8 / 16$ & $7 / 16$ & $8 / 14$ & $6 / 16$ & $0 / 16$ & $0 / 16$ \\
IR8 & $16 / 16$ & $6 / 16$ & $12 / 16$ & $9 / 16$ & $8 / 16$ & $11 / 16$ & $0 / 16$ & $0 / 15$ \\
\hline
\end{tabular}

${ }^{a}$ RNA transcripts representing F-BMV and the Russian strain of BMV (R-BMV) were made, reassorted, and inoculated to barley seedlings (cv. Morex). The progeny reassorted viruses from infected barley leaves were inoculated individually to rice seedlings (PI615210 and cv. IR8). Systemic infection of each reassortant virus in these two lines was determined by symptom development and immunocapture reverse transcriptase-polymerase chain reaction at 21 days postinoculation. The experiment was conducted three times, and in each experiment four to six plants were inoculated per reassorted virus.

${ }^{\mathrm{b}}$ Letters represent source of viral genomic RNAs 1, 2, and 3, respectively. F = F-BMV; R = R-BMV.

${ }^{\mathrm{c}}$ Number of plant infected/number of plants tested in three experiments. 
of F-BMV RNA 3 by replacing the existing IR with one from a modified RNA 3 of R-BMV that previously was shown to be responsible for a 2- to 2.5-fold increase in R-BMV RNA 3 and RNA 4 accumulation (Fig. 2B; Hema and Kao 2004). The resulting vector, containing RNAs 1 and 2 and the modified RNA 3 sequences of F-BMV, was named C-BMV $\mathrm{A} / \mathrm{G}$. To determine the relative pathogenicity and accumulation of $\mathrm{C}-\mathrm{BMV}_{\mathrm{A} / \mathrm{G}}$ in rice (cv. IR64), seedlings at 14 days after planting were in- oculated with $\mathrm{C}-\mathrm{BMV} \mathrm{A}_{\mathrm{A} / \mathrm{G}}, \mathrm{H}-\mathrm{BMV}$, or F-BMV. Plants inoculated with H-BMV developed mosaic symptoms at about 10 dpi and then became stunted compared with mock-inoculated plants. Younger leaves sometimes showed necrotic lesions at the later infection stage. Plants inoculated with $\mathrm{C}-\mathrm{BMV}_{\mathrm{A} / \mathrm{G}}$ or F-BMV developed mild mosaic symptoms by $10 \mathrm{dpi}$ and then became slightly stunted. All symptoms induced by these viruses were milder than symptoms caused by H-BMV (Fig. 5A). C-
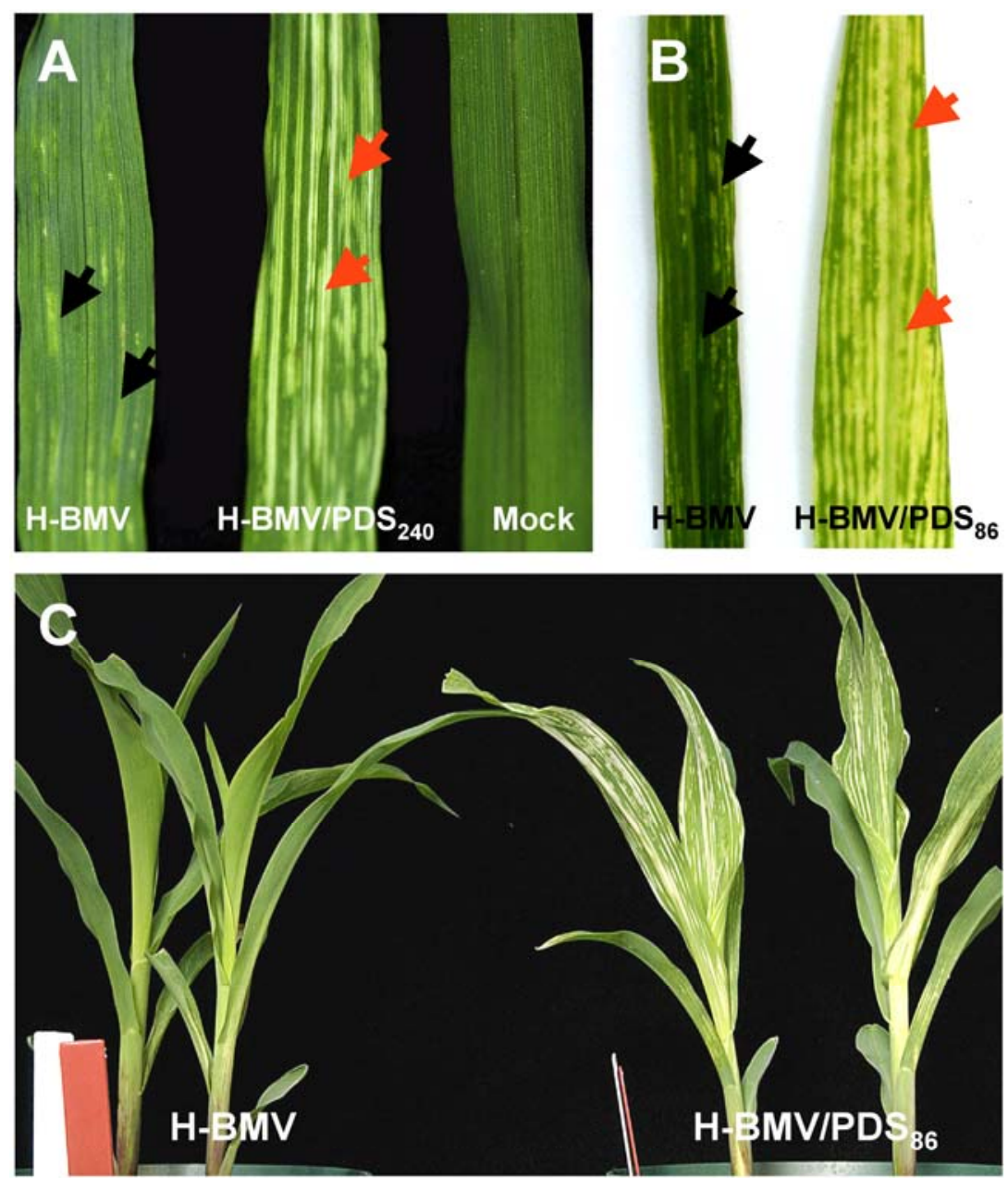

D

PCR cycle No. PCR cycle No. $\begin{array}{lllllllll}20 & 25 & 30 & 35 & 20 & 25 & 30 & 35\end{array}$

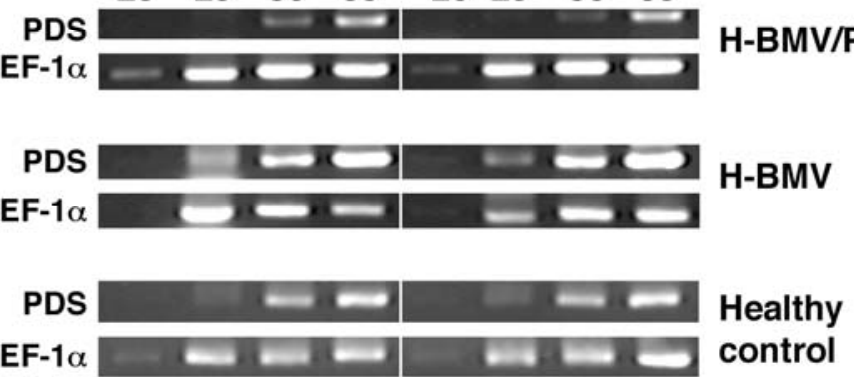

Fig. 3. Silencing phytoene desaturase (PDS) in barley, maize, and rice plants inoculated with the hybrid Brome mosaic virus (H-BMV)-based vector. Hybrid viruses containing 86- or 240-bp inserts $\left(\mathrm{H}-\mathrm{BMV} / \mathrm{PDS}_{86}\right.$ or $\mathrm{H}-\mathrm{BMV} \mathrm{PDS}_{240}$ ) were inoculated to seedlings of barley cv. Morex, and extracts from barley then were inoculated to maize cv. Va35 and rice PI615210. Healthy plants and plants inoculated with H-BMV without an insert (H-BMV) were used as controls. A, Second leaves above the inoculated leaves (second systemic leaves) of inoculated barley plants at 15 days postinoculation (dpi). Black arrows indicate yellow chlorosis caused by H-BMV and red arrows indicate the extensive light-yellow and white streaks caused by H-BMV/PDS 240 . B and C, Systemic leaves of inoculated rice and maize plants, respectively, at 21 dpi. Rice leaves shown are the second leaf above the inoculated leaf. Black arrows indicate chlorotic streaks induced by the H-BMV, and red arrows indicate the extensive light-yellow or white streaks caused by the H-BMV/PDS ${ }_{86}$ on rice. D, Systemic leaf tissues were collected from two representative maize plants inoculated with H-BMV, H-BMV/PDS ${ }_{86}$, or phosphate buffer at 14 dpi and were analyzed for PDS mRNA accumulation through semiquantitative reverse transcriptase-polymerase chain reaction (PCR). Levels of EF-1 $\alpha$ transcript in these tissues were determined as internal controls. PCR products obtained after 20,25, 30, and 35 cycles were visualized in $1.0 \%$ gels. 
$\mathrm{BMV}_{\mathrm{A} / \mathrm{G}} \mathrm{CP}$ accumulation in infected rice leaves was approximately half that determined for $\mathrm{H}-\mathrm{BMV}$ but approximately twofold higher than that determined for F-BMV (Fig. 5B and data not shown). Thus alteration of the IR of F-BMV RNA 3 resulted in a modified vector with a presumed benefit for VIGS studies.

To determine the usefulness of $\mathrm{C}-\mathrm{BMV}_{\mathrm{A} / \mathrm{G}}$ vector for VIGS in rice cv. IR64, seedlings were inoculated with RNA transcripts representing $\mathrm{C}-\mathrm{BMV}_{\mathrm{A} / \mathrm{G}}$ or $\mathrm{C}-\mathrm{BMV}_{\mathrm{A} / \mathrm{G}}$ containing an insert complementary to a portion of the rice ribulose-1,5-bisphosphate carboxylase/oxygenase (rubisco) activase (RA) gene (C$\left.\mathrm{BMV}_{\mathrm{A} / \mathrm{G}} / \mathrm{RA}_{200}\right)$. We previously observed a chlorosis and necrosis in $N$. benthamiana plants in which the RA transcript was down-regulated through VIGS using a TRV vector (A. Cole and R. S. Nelson, unpublished data). All virus-inoculated rice plants started to show systemic mosaic symptoms by $10 \mathrm{dpi}$. The plants inoculated with $\mathrm{C}-\mathrm{BMV}_{\mathrm{A} / \mathrm{G}} / \mathrm{RA}_{200}$ also developed necrotic spots on the second and third systemically infected leaves (Fig. 6A). No necrosis was observed on plants inoculated with $\mathrm{C}-\mathrm{BMV}_{\mathrm{A} / \mathrm{G}}$. Quantitative RT-PCR using extracts from symptomatic leaves harvested at $14 \mathrm{dpi}$ indicated that the RA transcript levels in plants inoculated with $\mathrm{C}-\mathrm{BMV}_{\mathrm{A} / \mathrm{G}} / \mathrm{RA}_{200}$

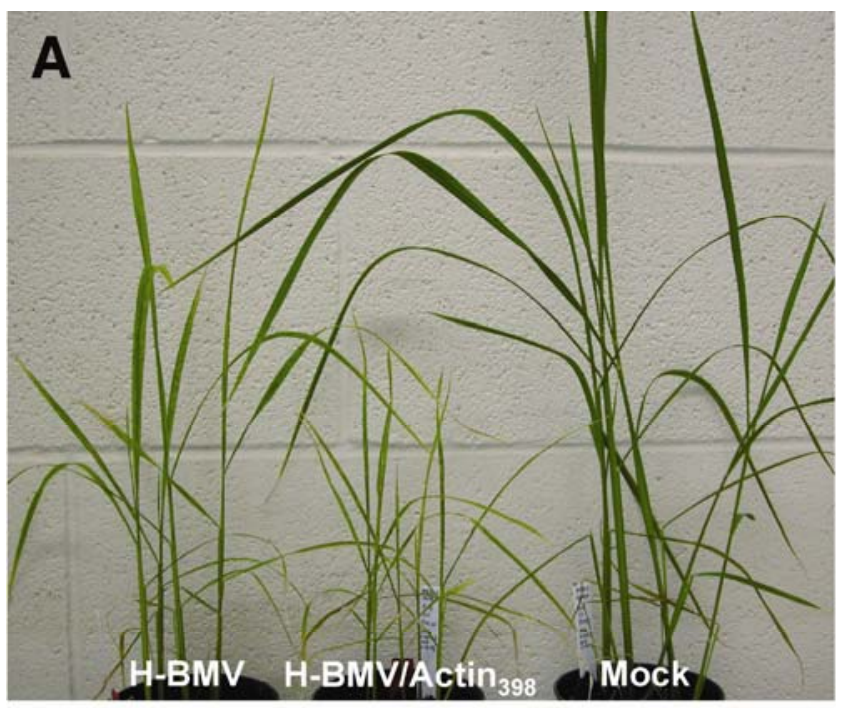

B

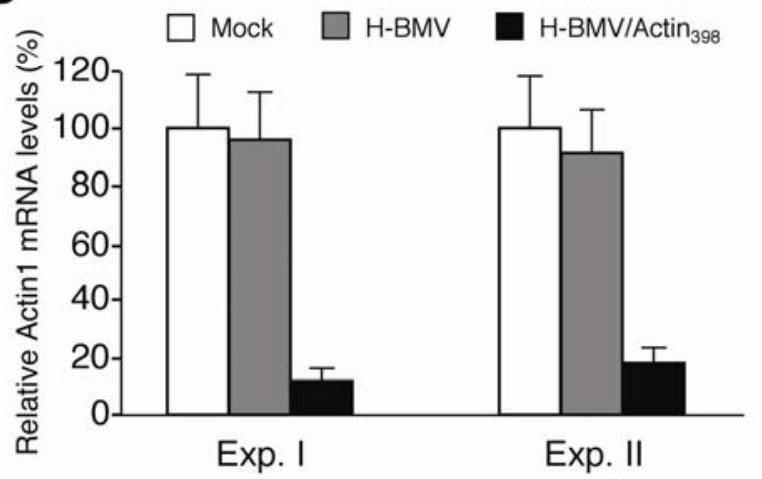

Fig. 4. Silencing actin 1 in rice inoculated with the H-BMV-based vector. Rice seedlings (cv. IR8) were inoculated with RNA transcripts representing H-BMV/Actin 398 and H-BMV. A, Inoculated plants were photographed at 21 days postinoculation (dpi). Note the stunted growth displayed by plants inoculated with H-BMV/Actin 398 . B, At 27 dpi, uninoculated leaves above the inoculated leaves from three plants per treatment were harvested and analyzed for actin 1 transcript levels through quantitative reverse transcriptase-polymerase chain reaction. Levels of rice EF-1 $\alpha$ transcript in each sampled tissue were determined as internal controls. Values represent the mean \pm standard error for sample replicates for each of two experiments. were approximately $6 \%$ the levels determined for plants inoculated with $\mathrm{C}-\mathrm{BMV}_{\mathrm{A} / \mathrm{G}}$ or phosphate buffer (Fig. 6B).

\section{DISCUSSION}

A strain of BMV, F-BMV, isolated from a breeding line of Festuca arundinacea Schreb. (Rouf Mian et al. 2005) has been cloned and sequenced, and infectious transcripts based on this virus have been characterized for their ability to infect other hosts and function in VIGS. The modified F-BMV vectors $\mathrm{H}$ $\mathrm{BMV}$ and $\mathrm{C}-\mathrm{BMV}_{\mathrm{A} / \mathrm{G}}$ were shown to infect rice, barley, and maize and to function as vectors for functional genomics studies in these hosts (Figs. 3, 4, and 6). Although BMV was used previously as an expression vector in protoplasts (e.g., French et al. 1986; Wojtkowiak et al. 2002), its utility for VIGS has never been demonstrated. The information reported here expands the number of virus vectors available for functional genomic studies in barley beyond BSMV (Hein et al. 2005; Scofield et al. 2005; Tai et al. 2005) and provides a unique resource for studies with rice and maize, in which no VIGS vector has been reported.

Although BMV can infect a broad range of plant species within the family Poaceae, it has been poorly studied for its ability to infect Oryza species. Previously, the infection of three of 18 rice cultivars or PIs by two isolates of BMV was demonstrated under greenhouse conditions, but the results were not reported in a peer-reviewed publication (Kahn and
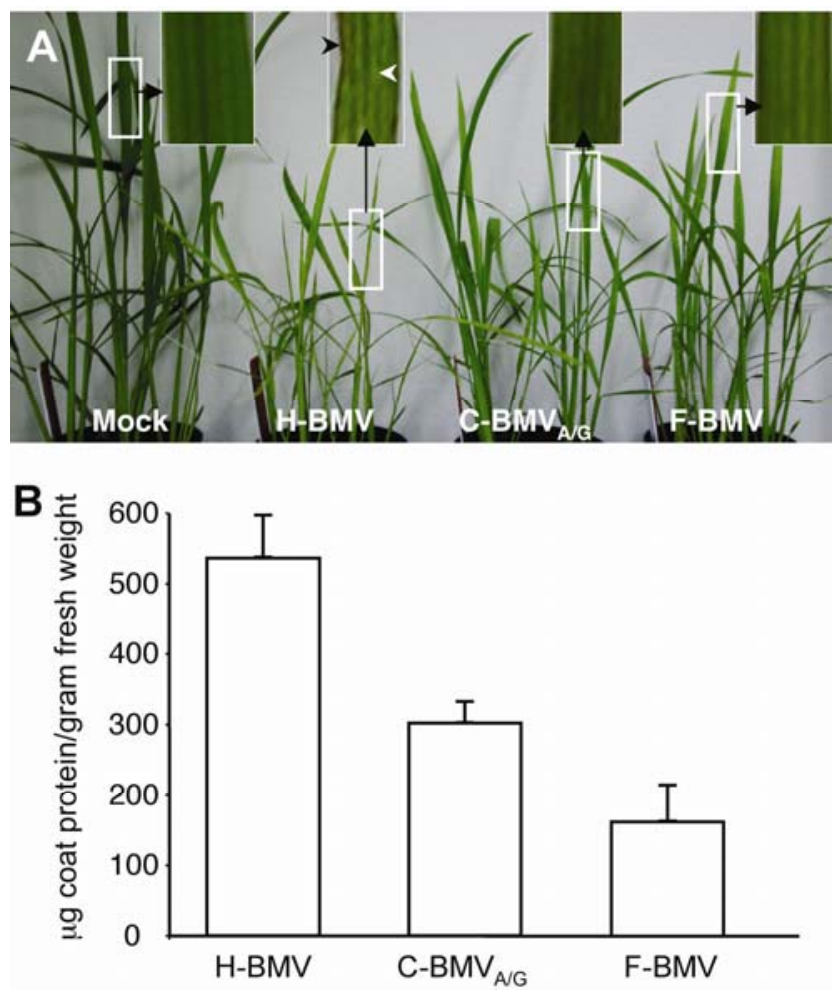

Fig. 5. Virus symptoms and accumulation in rice plants infected with the hybrid of Brome mosaic virus (H-BMV), chimeric (C)- $\mathrm{BMV}_{\mathrm{A} / \mathrm{G}}$, and the fescue strain of BMV (F-BMV). Seedlings of rice (PI615210) were inoculated with $\mathrm{H}-\mathrm{BMV}, \mathrm{C}-\mathrm{BMV}_{\mathrm{A} / \mathrm{G}}$, or F-BMV at 14 days after planting. A, At 17 days postinoculation (dpi), the plants were photographed and harvested. Plants infected with H-BMV developed much stronger mosaic with some necrosis (shown in the inserts, white and black arrowheads, respectively) and stunting symptoms compared with those infected with $\mathrm{C}$ $\mathrm{BMV}_{\mathrm{A} / \mathrm{G}}$ and F-BMV. Virus accumulation in each infected plant was determined at 17 dpi by enzyme-linked immunosorbent assay using an antibody specific for BMV coat protein. There were five replicates per treatment. Bars represent the standard error for each treatment. 
Dickerson 1957). The sources and other properties of the two BMV isolates that infected rice were not provided. It seems unlikely that F-BMV is identical to either of those strains, since it infected all rice cultivars and PIs we challenged (Fig. 1D). Also, it is unlikely that the strains identified in the earlier studies were identical to the well-characterized R-BMV strain, since R-BMV was unable to establish infection in any rice cultivars or PIs under our greenhouse conditions (Fig. 1D). The determinants for rice systemic infection mapped to RNAs 1 and 2 of F-BMV and sequences within RNA-3 of the virus enhanced infection of rice (Table 1).

The involvement of RNAs 1 and 2 of bromoviruses or cucumoviruses during the systemic infection of other host plants was observed previously by several research groups. Traynor and associates (1991) determined that BMV mutants containing deletions in the BMV 2a protein were capable of infecting barley protoplasts but were unable to establish a systemic infection in barley plants. Thus, a function for RNA 2 or 2 a protein was necessary for the systemic infection of barley by BMV. Allison and associates (1988) determined that either one or both of the RNAs 1 and 2 of BMV-Cowpea chlorotic mosaic virus (CCMV, also a member of the bromovirus group) reassorted viruses controlled systemic infection of barley. In an earlier study using two strains of CCMV (a wild-type and a resistance-breaking strain), Wyatt and Kuhn (1980) showed that RNA 1 of the resistance-breaking strain was responsible for the systemic infection of cowpea plants. For Cucumber mosaic virus, a tripartite RNA virus sharing significant sequence homology with BMV RNAs 1 and 2, it was determined that RNA 1 or 2 controlled the systemic infection of various hosts (Choi et al. 2005; Gal-On et al. 1994; Roossinck and Palukaitis 1990; Takeshita et al. 1998).

The mechanism by which the RNAs 1 and 2 or their protein products from the above examples regulate systemic infection in plants is unknown. The protein products of RNAs 1 and 2, 1a and $2 \mathrm{a}$, are required for the replication and accumulation of these viruses (Noueiry and Ahlquist 2003; Palukaitis and García-Arenal 2003). The 1a protein contains domains likely to have mRNA capping (methyltransferase) and RNA unwinding (helicase) activities. The $2 \mathrm{a}$ protein contains the polymerase domain. Both proteins are associated with plant membranes (Cillo et al. 2002; Restrepo-Hartwig and Ahlquist 1996). For $\mathrm{R}$ - and F-BMV, further studies are required in rice protoplasts to clarify whether the block in systemic accumulation by RBMV is due to the absence of local replication or to lack of systemic movement. However, further conclusions about the mechanism responsible for the systemic infection of rice by FBMV can be made through analyzing the positions of the amino-acid substitutions. The putative amino acid differences between the 1a protein of F-BMV and R-BMV are spread throughout the protein. However, none of the substitutions reside within the region that defines the primary membrane-association determinants in the 1a protein (aa residues 367 to 480; den Boon et al. 2001). Although other regions within the 1a protein affect membrane association, it is worth speculating, from this information, that the ability of F-BMV to infect rice is not due to an altered ability of the 1a protein to associate with host membranes. The altered amino-acid residues in the 1a protein are found in the regions associated with RNA capping, 1a-2a and 1a-1a interactions and helicase activity (O'Reilly et al. 1997, 1998). Whether a host factor interaction with viral proteins has been directly affected (e.g., RNA capping) or indirectly affected due to poor viral protein interaction (e.g., 1a-2a interaction) requires study.

The use of BMV as a VIGS vector yielded multiple observations for further discussion. Regarding the size of silencing inducer sequence, we used vectors harboring from 86 (PDS) up to $398 \mathrm{bp}$ (actin 1) inserts for VIGS in various plants. From our observations, it is clear that the addition of up to $398 \mathrm{bp}$ of host sequence to the viral genome did not cause this genomic RNA to exceed the size capacity of the capsid, a severe limitation for viruses that form icosahedral capsids (Lacomme et al. 2001). Evidence exists that capsid formation may be necessary for BMV cell-to-cell movement (Kasteel et al. 1997; Rao and Grantham 1996), although results from other studies question this theory (Flasinski et al. 1995; Takeda et al. 2005).

Although the modified viral RNA with insert could be maintained for a period of time in systemic tissue, the insert may be unstable irrespective of its ability to form a capsid. Insert instability may explain the transient silencing phenotype we observed in our studies; visual silencing phenotypes for PDS and RA were generally lost by the fourth systemically infected leaf. Similar losses of visual phenotype in barley and wheat after inoculation with the BSMV vector expressing a PDS insert have been reported (Holzberg et al. 2002; Scofield et al.
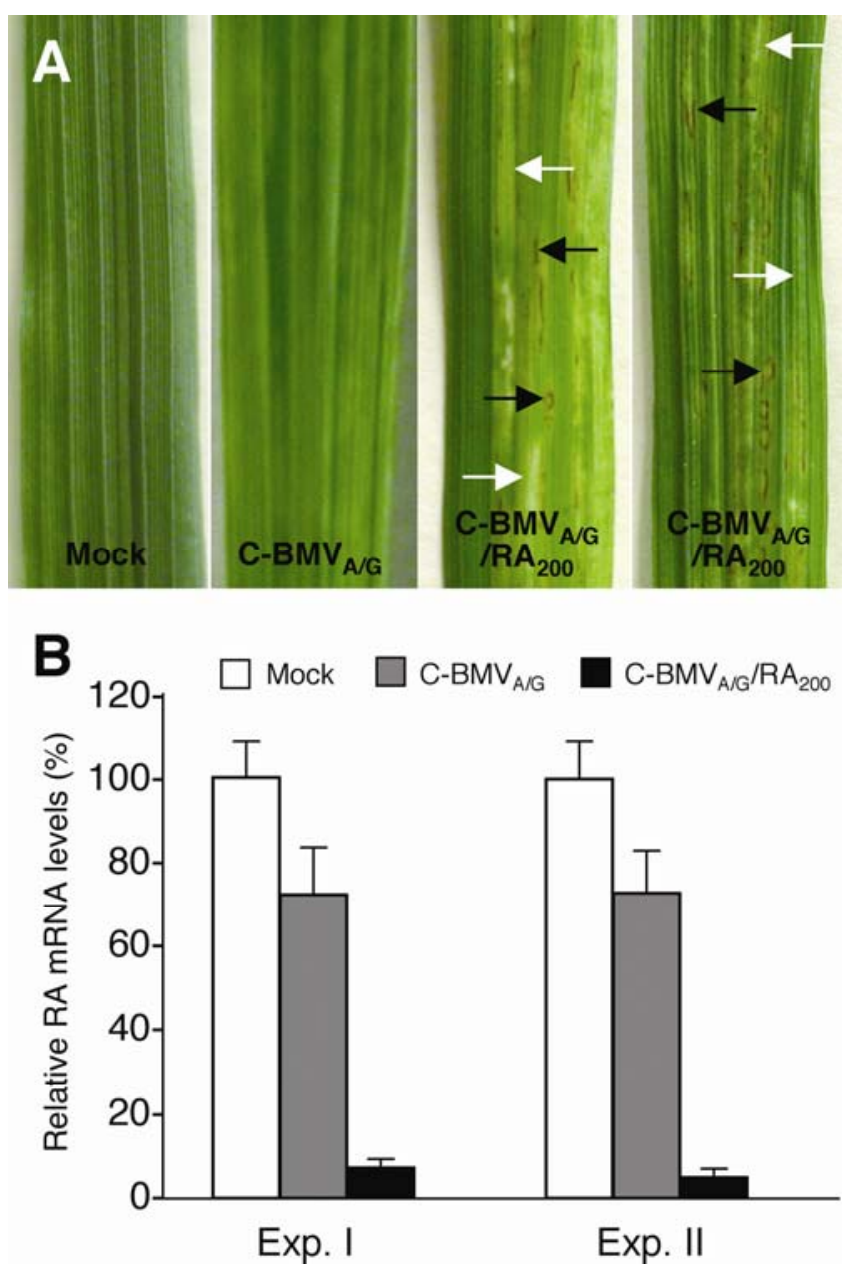

Fig. 6. Silencing rubisco activase (RA) in rice inoculated with the chimeric Brome mosaic virus $(\mathrm{C}-\mathrm{BMV})_{\mathrm{A} / \mathrm{G}}$-based vector. Rice seedlings (cv. IR64) were inoculated with RNA transcript representing $\mathrm{C}-\mathrm{BMV}_{\mathrm{A} / \mathrm{G}}$ or $\mathrm{C}-\mathrm{BMV}_{\mathrm{A} / \mathrm{G}}$ with an RA insert $\left(\mathrm{C}-\mathrm{BMV}_{\mathrm{A} / \mathrm{G}} / \mathrm{RA}_{200}\right)$. $\mathbf{A}$, Developmentally matched uninoculated leaves above the inoculated leaves were photographed at 35 days postinoculation (dpi). Leaf pictured at far right is from one node above those pictured to the left. Arrows point to chlorosis (white) and necrosis (black) induced by $\mathrm{C}-\mathrm{BMV}_{\mathrm{A} / \mathrm{G}} / \mathrm{RA}_{200}$ not present in tissue infected with $\mathrm{C}$ $\mathrm{BMV}_{\mathrm{A} / \mathrm{G}}$ or in buffer-inoculated tissue (Mock). B, Inoculated plants were sampled and analyzed for RA transcript levels through quantitative reverse transcriptase-polymerase chain reaction at $14 \mathrm{dpi}$. Levels of rice EF-1 $\alpha$ transcript in each sampled tissue were determined as internal controls. Values represent the mean \pm standard error for sample replicates for two experiments. 
2005). Other researchers determined that foreign inserts, especially the larger inserts (in one instance only 300 nucleotides in length), resulted in genetic instability of the replicating virus vector or less vector RNA accumulation (Gosselé 2002; Lacomme et al. 2003; Lu et al. 2003a). The reason for genetic instability of foreign inserts in viruses is not understood. It is possible that an aberrant form of the viral RNA, due to the foreign gene insert, is recognized by the virus-host replication complex and the nonnative region is deleted through homologous recombination (Urbanowicz et al. 2005).

We also observed that the PDS silencing phenotype did not penetrate throughout the lamina of barley, maize, and rice leaves displaying silencing phenotypes (Fig. 3A to C). A similar observation was made in the wheat-BSMV/PDS system (Scofield et al. 2005). These authors noted that barley displayed a more complete silencing throughout the leaf lamina compared with that of wheat; thus, the host background can influence the level of phenotype penetration through the leaf. The lack of silencing throughout an affected leaf may be due to the absence of virus in the nonsymptomatic regions or to the failure of the expressed insert to induce silencing. Lacomme and associates (2003) reported that the BSMV vector harboring direct inverted repeats of barley PDS gene caused stronger and more pervasive silencing phenotypes in barley plants compared with those caused by the vector carrying corresponding inserts in sense or antisense direction. They also showed, using a TMV vector, that direct inverted repeats generating a loopless dsRNA structure could induce more intense silencing phenotypes than those harboring inverted repeats with hairpinlike structures. Analyzing gene silencing in rice and maize plants, using a BMV vector containing various hairpin-like structures, is under investigation.

Interestingly, in contrast to the visual PDS gene silencing phenotype in rice, the visual actin 1 silencing phenotype in rice was more stable. The stunting phenotype was maintained well beyond when the PDS silencing phenotype was lost (Fig. 4A) and was similar to but milder than the phenotype in $N$. benthamiana plants infected with TRV harboring an insert from the tobacco actin gene (Liu et al. 2005; J. Z. Liu and R. S. Nelson, unpublished data). The reason why the actin 1 gene-silencing phenotype in rice was more stable than the PDS gene-silencing phenotype in rice is unclear. It may be that both silencing phenotypes are transient, but the actin-induced phenotype appears stable because silencing two or three nodes for actin expression permanently stunts those plants as compared with controls, even if later growth is normal. However, the actin 1 gene insert is maintained longer in vector in the systemic rice leaf tissues (up to $40 \mathrm{dpi}$ ) than is the PDS insert (data not shown). Further research is necessary to understand the causes of the transient and incomplete silencing often observed in the monocot systems.

\section{MATERIALS AND METHODS}

\section{Virus and plant sources.}

An infected breeding stock of tall fescue (Festuca arundinacea Schreb.) was the source of the monocotyledonous virus characterized and cloned in this study (Rouf Mian et al. 2005). Due to its ability to infect tall fescue and its physical and molecular characteristics reported previously (Rouf Mian et al. 2005) and in this study, the virus was named F-BMV. The common strain of BMV, R-BMV, was from a previously described source (Ding et al. 1999). Both virus isolates were maintained in barley cv. Morex plants grown in growth chambers at $24^{\circ} \mathrm{C}$ day and $18^{\circ} \mathrm{C}$ night, $16 \mathrm{~h}$ light and $8 \mathrm{~h}$ dark cycles.

Rice seeds for cv. IR8 were provided by S. Dai (Donald Danforth Plant Science Center, St. Louis) and cv. Drew by K.
Korth (University of Arkansas, Fayetteville, AR, U.S.A.), and cvs. IR64, PI615200, PI615210, PI64981, PI64984, and PI64987 were obtained from the National Small Grains Collection (Aberdeen, ID, U.S.A.). Seeds of barley cv. Morex and maize cv. Va35 were obtained from previously described sources (Ding et al. 2001).

\section{Plant inoculation.}

Seedlings were inoculated with virus at 10 to 14 days postgermination. The inoculated plants, except barley, were grown in a greenhouse at $25^{\circ} \mathrm{C}$ day and $21^{\circ} \mathrm{C}$ night temperatures. A 16-h photoperiod was maintained inside the greenhouse, through illumination with high-pressure sodium lamps producing a light intensity of approximately $140 \mu \mathrm{mol}$ photons $\mathrm{m}^{-2} \mathrm{~s}^{-1}$. Virus-inoculated barley plants were grown in a growth chamber as described (Ding et al. 1999).

\section{Cloning and sequencing F-BMV and R-BMV.}

Virions of F-BMV and R-BMV were purified from infected barley leaves through polyethylene glycol precipitation and differential centrifugation (Lane 1981). Viral RNA was isolated from purified virions through phenol/chloroform extraction and ethanol precipitation. cDNAs of BMV RNAs 1, 2, and 3 were synthesized by priming the $3^{\prime}$ end of each viral RNA with Primer HK-R (5'-GACAATGGTCTCTTTTAGAG-3') followed by first-strand extension, using SuperScript reverse transcriptase as described by the manufacturer (Invitrogen, Carlsbad, CA, U.S.A.) . The $5^{\prime}$ nucleotides within the HK-R primer contain a PshA1 restriction site (shown in italics), while the $3^{\prime}$ nucleotides contain the sequence complementary to the $3^{\prime}$ ends of the three R-BMV RNAs (Ahlquist et al. 1981, 1984). Full-length PCR products of RNAs 1, 2, and 3 were synthesized using the HK-R primer and primers containing sequences corresponding to the T3 promoter sequence (underlined) and the $5^{\prime}$ end of the respective R-BMV RNA sequences (i.e., HK-1F, 5'-AATT AACCCTCACTAAAGGGAGAGTAGACCACGGAACGAGG T-3' for RNA 1; HK-2F, 5'-AATTAACCCTCACTAAAGGGA GAGTAAACCACGGAACG-3' for RNA 2; and HK-3F, 5'AATTAACCCTCACTAAAGGGAGAGTAAAATACCAACT-

3' for RNA 3). Thermal cycling reactions were conducted with a mixture of $T a q$ DNA polymerase (Roche, Indianapolis, IN, U.S.A.) and $P f u$ DNA polymerase (7:1, vol/vol; Stratagene, La Jolla, CA, U.S.A.) for maximum polymerase fidelity. The resulting PCR products were gel-purified and ligated individually into the pGEM T-Easy vector (Promega, Madison, WI, U.S.A.) (Fig. 2A). Transformation of JM109 competent cells was performed as instructed (Promega). Individual full-length clones representing viral genomic RNAs (three clones each for F-BMV RNAs 1 and 3; four clones for F-BMV RNA 2) were sequenced using sequence-specific primers and a sequencer (model 7900; Applied Biosystems, Foster City, CA, U.S.A.). FBMV sequences were compared with published sequences of R-BMV (Ahlquist et al. 1981, 1984) using DNASTAR Clustal V (DNASTAR, Madison, WI, U.S.A.). Full-length clones representing R-BMV RNAs 1, 2, and 3 were also prepared and sequenced as described for the F-BMV clones above. Plasmids representing RNA 1 of F-BMV (pF1-11) and R-BMV (pB1-26) were linearized with SpeI enzyme, and plasmids representing RNAs 2 and 3 of F-BMV (pF2-2 and pF3-5) and R-BMV (pB2-4 and pB3-3) were linearized with PshAI for synthesis of capped infectious transcript through in vitro transcription and capping using the mMESSAGE mMACHINE kit (Ambion, Austin, TX, U.S.A.).

\section{Preparation and analysis of reassorted viruses.}

To identify the one or more viral determinants in F-BMV necessary to infect rice, RNA transcripts were synthesized from the 
linearized plasmids as described above. Equal quantities of transcripts representing genomic RNAs of either F-BMV or R-BMV were mixed and inoculated to leaves of $C$. quinoa (5 to $6 \mu \mathrm{l}$ of mixed reassorted transcripts per leaf; two leaves per plant). Single chlorotic lesions observed on the inoculated $C$. quinoa leaves were individually collected at $6 \mathrm{dpi}$, were ground in $0.02 \mathrm{M}$ phosphate buffer (PB), pH 6.0 (1 lesion per $50 \mu \mathrm{l}$ ), and the extract was inoculated to leaves of barley plants. Crude extracts from systemically infected leaves of barley were then used to inoculate leaves of rice cv. IR8 and PI615210. Four to six plants per rice cultivar were inoculated with each of the eight reassorted viruses (e.g., FFF, FFR, FRF, RFF, RRR, RRF, RFR, and FRR), and the experiment was repeated twice.

Virus infection in the inoculated rice plants was determined by symptom observation, biological assay, or immunocapture RT-PCR (Jacobi et al. 1998) with modifications. Modifications were that leaves of rice plants were ground in $\mathrm{PB}, \mathrm{pH} 7.0$, and an aliquot $(30 \mu \mathrm{l})$ from each sample was placed in a $0.5-\mathrm{ml}$ microfuge tube precoated with an antibody against the R-BMV coat protein (1:5000 dilution, vol/vol; Ding et al. 2001). The tubes were incubated overnight at $4^{\circ} \mathrm{C}$. After three washes with distilled water, RNAs from bound virions were amplified by RT-PCR, using primers HK-R and B3 F (5'-GAATAAGGA GCTTAAGGTCGG-3'; complementary to nucleotides 1,490 to 1,510 of R-BMV RNA3). The resulting PCR products were visualized by electrophoresis in $1.0 \%$ agarose gels.

\section{Modification of F-BMV RNA 3.}

To minimize disease symptoms caused by the H-BMV vector in various host plants, a $B c l \mathrm{I} / B s \mathrm{BHI}$ fragment was released from the SI13'A/G construct (Hema and Kao 2004) and was ligated into the pF3-5 construct predigested with the BclI and BssHII enzymes. The modified $\mathrm{pF} 3-5$ was altered at the initiation sequence for the subgenomic RNA 4 and was referred to as pF3$5 / 13^{\prime}{ }_{\mathrm{A} / \mathrm{G}}$ (Fig. 2B; synonym, pC-BMV RNA3 $3_{\mathrm{A} / \mathrm{G}}$ ). The progeny virus (referred to as $\mathrm{C}-\mathrm{BMV}_{\mathrm{A} / \mathrm{G}}$ ) was analyzed for its pathogenicity in rice through symptom observation and its replication through enzyme-linked immunosorbent assay, as described previously (Barbara and Clark 1982; Ding et al. 2001).

\section{Insertion of foreign gene fragments and transcript inoculation.}

PCR fragments of 86 and 240 bp were obtained for the maize PDS (Li et al. 1996) gene, using primers PDS F1 (5'-C ATAAGCTTCTCGAGTGTTCATATATGGTTT-3') and PDS R1 (5'-CATAAGCTTAGACACTTAAAAGTGAACTC-3'), and PDS F1 and PDS R2 (5'-CATAAGCTTTCATCTGGAAACAA CTTGGC-3'), respectively. A PCR fragment of 398 bp of the rice actin 1 gene (accession number XM 475316) was amplified using primers Act F1 (5'-CATAAGCTTATTATGAGCAG GAGCTGGGA-3') and Act R1 (5'-CATAAGCTTTCTGCTGG AATGTGCTGAGA-3'). A 200-bp PCR fragment of the rice RA gene (To et al. 1999) was amplified using primer RA F1 (5'-CATAAGCTTGGTGCAGGTCGCATGGGAGGC -3') and RA R1 (5'-CATAAGCTTCGCCCGTCACGGATGAGCGG-3'). Each primer contained a HindIII restriction site (shown in italics). The resulting PCR fragments were digested with HindIII and were ligated into the HindIII site of the pB3-3 or pF3$5 / 13^{\prime}{ }_{\mathrm{A} / \mathrm{G}}$ construct. The modified vector constructs (pB3$3 / \mathrm{PDS}_{86}, \mathrm{pB} 3-3 / \mathrm{PDS}_{240}, \mathrm{pB} 3-3 / \mathrm{Act}_{398}$, and $\mathrm{pF} 3-5 / 13^{\prime}{ }_{\mathrm{A} / \mathrm{G}} / \mathrm{RA}_{200}$ ) were sequenced to verify sequence authenticity. RNA transcripts synthesized from the $\mathrm{pB} 3-3 / \mathrm{PDS}_{86}, \mathrm{pB} 3-3 / \mathrm{PDS}_{240}, \mathrm{pB} 3-3 / \mathrm{Act}_{398}$, or $\mathrm{pF} 3-5 / 13^{\prime}{ }_{\mathrm{A} / \mathrm{G}} / \mathrm{RA}_{200}$ were mixed with those from $\mathrm{pF} 1-11$ and $\mathrm{pF} 2-2$. The resulting progeny viruses were referred to as $\mathrm{H}-\mathrm{BMV} / \mathrm{PDS}_{86}, \mathrm{H}-\mathrm{BMV} / \mathrm{PDS}_{240}, \mathrm{H}-\mathrm{BMV} \mathrm{Act}_{398}$, and C$\mathrm{BMV}_{\mathrm{A} / \mathrm{G}} / \mathrm{RA}_{200}$. The infectious transcripts of $\mathrm{H}-\mathrm{BMV} / \mathrm{PDS}_{86}$, H-BMV/PDS $240, \mathrm{H}-\mathrm{BMV}_{2} \mathrm{Act}_{398}$, and H-BMV (a control virus without an insert) were inoculated to leaves of barley and Chenopodium amaranticolor (5 to $6 \mu \mathrm{l}$ mixed transcripts per leaf, one leaf per plant). Systemically infected barley leaves were collected at 10 to $14 \mathrm{dpi}$ and were ground in $\mathrm{PB}, \mathrm{pH}$ 6.0, and the extract was inoculated to leaves of maize and rice plants. Plants inoculated with PB alone were used as mockinoculated controls. The infectious transcripts of $\mathrm{C}-\mathrm{BMV}_{\mathrm{A} / \mathrm{G}} /$ $\mathrm{RA}_{200}$ and $\mathrm{C}-\mathrm{BMV}_{\mathrm{A} / \mathrm{G}}$ (a control virus without an insert) were each diluted with FES buffer (Scofield et al. 2005; $1 \mu \mathrm{l}$ from each transcript reaction, representing each genomic component, were mixed and diluted to $60 \mu \mathrm{l}$ of total volume with buffer) and were inoculated directly to leaves of rice and C. amaranticolor plants $(20 \mu \mathrm{l}$ inoculum per plant). The inoculated $C$. amaranticolor, maize, and rice plants were grown in a greenhouse for approximately four weeks.

\section{Analysis of PDS, actin 1, and RA transcripts in plants.}

To determine if the H-BMV vector containing PDS sequence could induce PDS gene silencing in maize and rice, the uninoculated younger leaves of each inoculated maize plant were harvested at $21 \mathrm{dpi}$ and total RNA was extracted from them, using TRIzol reagent (Invitrogen). Synthesis of cDNAs was performed using an oligo dT primer (Integrated DNA Technologies, Coralville, IA, U.S.A.). PDS gene expression in each sample was then determined through semiquantitative RT-PCR using primers PDS F1 and PDS R3 (5'-CATAAGCTTGTGT AGTCACCAGCTAGATAG-3'). Elongation factor $1 \alpha(\mathrm{EF}-1 \alpha)$ transcript was quantified, using primers EF F1 (5'-GAGGC ATTGACAAGCGTGTGATCGAGAGG-3') and EF R1 (5'-CC CTCAAACCCAGAGATGGGAACGAAGGGG-3') as the internal nontargeted control. PCR products collected after 20, 25, 30 , and 35 cycles were visualized in $1.0 \%$ agarose gels, using a BioImaging System (UVP, Ultra-Violet Products, Upland, CA, U.S.A.).

For actin 1 and RA gene expression in rice, total RNA was extracted from rice leaves at 27 (actin 1) and 14 (RA) dpi and was analyzed through quantitative RT-PCR described previously (Ryu et al. 2004). Equal amounts of total RNA from three independent plants per treatment were pooled, and $2 \mu \mathrm{g}$ of pooled RNA from each pooled sample was used for reverse transcription using an oligo dT primer. Primers used to quantify the actin $1, \mathrm{RA}$, and EF- $1 \alpha$ gene mRNA were Act F2 (5'TACAGCGTCTGGATTGGTGGT-3') and Act R2 (5'-TGG CAAGAAGCTCAGAAGCAC-3') for actin 1 gene mRNA, RA F2 (5'-TTCATGGACAAGCTCGTCGTC-3') and RA R2 (5'AGGATTTTCCCTGACCCTTGC-3') for the RA gene, and EF F2 (5'-CCGCCAAGAAGAAATGAGCA-3') and EF R2 (5'TCCATGCAACGAGTGCCAT-3') for the EF-1 $\alpha$ gene. Actin 1 and RA mRNA levels in various plants were calculated using the standard curve method (Applied Biosystems Inc., Foster City, CA, U.S.A.) and were normalized against the EF-1 $\alpha$ transcript levels. All samples were run in triplicate. Variation between samples was expressed as standard error of the mean for three replicates per treatment. Experiments for both actin 1 and RA transcript analyses were repeated.

\section{ACKNOWLEDGMENTS}

We acknowledge G.-L. Wang and his laboratory personnel for supplying an actin 1 gene fragment for our work. We thank E. Blancaflor and J. Pita for valuable comments on the manuscript, K. Ballard and Y. Chen for technical assistance in conducting experiments, F. Coker and K. Richerson for maintenance of plants in the greenhouse, C. Ly for figure preparation, and A. Perkins for reference collection and formatting. This research was funded by a United States Agency for International Development linkage grant administered through the International Rice Research Institute (IRRI reference number DPPC 2004-49) to R. S. Nelson and the Samuel Roberts Noble Foundation. 


\section{LITERATURE CITED}

Ahlquist, P. 1999. Bromoviruses (Bromoviridae). Pages 198-204 in: Encyclopedia of Virology. A. Granoff and R.G. Webster, eds. Academic Press, San Diego, CA, U.S.A.

Ahlquist, P., Luckow, P., and Kaesberg, P. 1981. Complete nucleotide sequence of brome mosaic virus RNA3. J. Mol. Biol. 152:23-38.

Ahlquist, P., Dasgupta, R., and Kaesberg, P. 1984. Nucleotide sequence of the brome mosaic virus genome and its implications for viral replication. J. Mol. Biol. 172:369-383.

Al-Kaff, N. S., Covey, S. N., Kreike, M. M., Page, A. M., Pinder, R., and Dale, P. J. 1998. Transcriptional and posttranscriptional plant gene silencing in response to a pathogen. Science 279:2113-2115

Allison, R. F., Janda, A., and Ahlquist, P. 1988. Infectious in vitro transcripts from cowpea chlorotic mottle virus cDNA clones and exchange of individual RNA components with brome mosaic virus. J. Virol. 62:3581-3588.

Barbara, D. J., and Clark, M. F. 1982. A simple indirect ELISA using $\mathrm{F}\left(\mathrm{ab}^{\prime}\right)_{2}$ fragments of immunoglobulin. J. Gen. Virol. 58:315-322

Baulcombe, D. 2004. RNA silencing in plants. Nature 431:356-363

Burch-Smith, T. M., Anderson, J. C., Martin, G. B., and Dinesh-Kumar, S. P. 2004. Applications and advantages of virus-induced gene silencing for gene function studies in plants. Plant J. 39:734-746.

Choi, S. K., Palukaitis, P., Min, B. E., Lee, M. Y., Choi, J. K., and Ryu, K. H. 2005. Cucumber mosaic virus 2 a polymerase and 3 a movement proteins independently affect both virus movement and the timing of symptom development in zucchini squash. J. Gen. Virol. 86:1213-1222.

Cillo, F., Roberts, I. M., and Palukaitis, P. 2002. In situ localization and tissue distribution of the replication-associated proteins of Cucumber mosaic virus in tobacco and cucumber. J. Virol. 76:10654-10664.

Constantin, G. D., Krath, B. N., MacFarlane, S. A., Nicolaisen, M., Johansen, I. E., and Lund, O. S. 2004. Virus-induced gene silencing as a tool for functional genomics in a legume species. Plant J. 40:622-631.

Covey, S. N., and Al-Kaff, N. S. 1997. Plants combat infection by gene silencing. Nature 385:781-782.

Dasgupta, R., and Kaesberg, P. 1982. Complete nucleotide sequences of the coat protein messenger RNAs of brome mosaic virus and cowpea chlorotic mottle virus. Nucleic Acids Res. 10:703-713.

den Boon, J. A., Chen, J., and Ahlquist, P. 2001. Identification of sequences in brome mosaic virus replicase protein 1a that mediate association with endoplasmic reticulum membranes. J. Virol. 75:12370-12381

Ding, X. S., Flasinski, S., and Nelson, R. S. 1999. Infection of barley by brome mosaic virus is restricted predominantly to cells in and associated with veins through a temperature-dependent mechanism. Mol. Plant-Microbe Interact. 12:615-623.

Ding, X. S., Boydston, C. M., and Nelson, R. S. 2001. Presence of Brome mosaic virus in barley guttation fluid and its association with localized cell death response. Phytopathology 91:440-448.

Flasinski, S., Dzianott, A., Pratt, S., and Bujarski, J. J. 1995. Mutational analysis of the coat protein gene of brome mosaic virus: Effects on replication and movement in barley and in Chenopodium hybridum. Mol. Plant-Microbe Interact. 8:23-31.

French, R., Janda, M., and Ahlquist, P. 1986. Bacterial gene inserted in an engineered RNA virus: Efficient expression in monocotyledonous plant cells. Science 231:1294-1297.

Fu, D. Q., Zhu, B. Z., Zhu, H. L., Jiang, W. B., and Luo, Y. B. 2005. Virusinduced gene silencing in tomato fruit. Plant J. 43:299-308.

Gal-On, A., Kaplan, I. B., Roossinck, M. J., and Palukaitis, P. 1994. The kinetics of infection of zucchini squash by cucumber mosaic virus indicate a function of RNA 1 in virus movement. Virology 205:280-289

Gosselé, V., Faché, I., Meulewaeter, F., Cornelissen, M., and Metzlaff, M. 2002. SVISS-A novel transient gene silencing system for gene function discovery and validation in tobacco plants. Plant J. 32:859-866.

Hein, I., Barciszewska-Pacak, M., Hrubikova, K., Williamson, S., Dinesen, M., Soenderby, I. E., Sundar, S., Jarmolowski, A., Shirasu, K., and Lacomme, C. 2005. Virus-induced gene silencing-based functional characterization of genes associated with powdery mildew resistance barley. Plant Physiol. 138:2155-2164.

Hema, M., and Kao, C. C. 2004. Template sequence near the initiation nucleotide can modulate brome mosaic virus RNA accumulation in plant protoplast. J. Virol. 78:1169-1180.

Holzberg, S., Brosio, P., Gross, C., Pogue, G. P. 2002. Barley stripe mosaic virus-induced gene silencing in a monocot plant. Plant J. 30:315327

Jacobi, V., Bachand, G. D., Hamelin, R. C., and Castello, J. D. 1998. Development of a multiplex immunocature RT-PCR assay for detection and differentiation of tomato and tobacco mosaic tobamoviruses. J. Virol. Methods 74:167-178

Kahn, R. P., and Dickerson, D. J. 1957. Susceptibility of rice to systemic infection by three common cereal viruses. Phytopathology 47:526.
Kao, C. C., and Ahlquist, P. 1992. Identification of the domains required for direct interaction of the helicase-like and polymerase-like RNA replication proteins of brome mosaic virus. J. Virol. 66:7293-7302.

Kao, C. C., and Sivakumaran, K. 2000. Brome mosaic virus, good for an RNA virologist's basic needs. Mol. Plant Pathol. 1:91-97.

Kasteel, D. T. J., van der Wel, N. N., Jansen, K. A. J., Goldbach, R. W., and van Lent, J. W. M. 1997. Tubule-forming capacity of the movement proteins of alfalfa mosaic virus and brome mosaic virus. J. Gen. Virol. 78:2089-2093

Kiberstis, P. A., Loesch-Fries, L. S., and Hall, T. C. 1981. Viral protein synthesis in barley protoplasts inoculated with native and fractionated brome mosaic virus RNA. Virology 112:804-808.

Kjemtrup, S., Sampson, K. S., Peele, C. G., Nguyen, L. V., Conkling, M. A., Thompson, W. F., and Robertson, D. 1998. Gene silencing from plant DNA carried by a geminivirus. Plant J. 14:91-100

Kroner, P., Richards, D., Traynor, P., and Ahlquist, P. 1989. Defined mutations in a small region of the brome mosaic virus 2 a gene cause diverse temperature-sensitive RNA replication phenotypes. J. Virol. 63:53025309

Kroner, P., Young, B. M., and Ahlquist, P. 1990. Analysis of the role of brome mosaic virus 1a protein domains in RNA replication, using linker insertion mutagenesis. J. Virol. 64:6110-6120

Kumagai, M. H., Donson, J., Della-Cioppa, G., Harvey, D., Hanley, K., and Grill, L. K. 1995. Cytoplasmic inhibition of carotenoid biosynthesis with virus-derived RNA. Proc. Natl. Acad. Sci. U.S.A 92:1679-1683.

Lacomme, C., Pogue, G. P., Wilson, T. M. A., and Santa Cruz, S. 2001. Plant viruses. Pages 59-105 in: Genetically Engineered Viruses: Development and Applications. C. J. A. Ring and E. D. Blair, eds. BIOS Scientific Publishers, Oxford.

Lacomme, C., Hrubikova, K., and Hein, I. 2003. Enhancement of virus-induced gene silencing through viral-based production of inverted-repeats. Plant J. 34:543-553.

Lane, L. C. 1981. Bromoviruses. Pages 333-375 in: Handbook of Plant Virus Infections Comparative Diagnosis. E. Kurstak, ed. Elsevier/ North Holland Biomedical Press, Amsterdam.

Li, Z. H., Matthews, P. D., Burr, B., and Wurtzel, E. T. 1996. Cloning and characterization of a maize cDNA encoding phytoene desaturase, an enzyme of the carotenoid biosynthetic pathway. Plant Mol. Biol. 30:269-279

Liu, J.-Z., Blancaflor, E. B., and Nelson, R. S. 2005. The Tobacco mosaic virus 126-kilodalton protein, a constituent of the virus replication complex, alone or within the complex aligns with and traffics along microfilaments. Plant Physiol. 138:1853-1865.

Liu, Y., Schiff, M., Marathe, R., and Dinesh-Kumar, S. P. 2002. Tobacco Rarl, EDS1 and NPR1/NIM1 like genes are required for $N$-mediated resistance to tobacco mosaic virus. Plant J. 30:415-429.

Lu, R., Martin-Hernandez, A. M., Peart, J., Malcuit, I., and Baulcombe, D. 2003a. Virus-induced gene silencing in plants. Methods 30:296-303.

Lu, R., Malcuit, I., Moffett, P., Ruiz, M. T., Peart, J., Wu, A.-J., Rathjen, J. P., Bendahmane, A., Day, L., and Baulcombe, D. C. 2003b. High throughput virus-induced gene silencing implicates heat shock protein 90 in plant disease resistance. EMBO (Eur. Mol. Biol. Organ.) J. 22:5690-5699.

Meister, G., and Tuschl, T. 2004. Mechanisms of gene silencing by double-stranded RNA. Nature 431:343-349

Mello, C. C., and Conte, D., Jr. 2004. Revealing the world of RNA interference. Nature 431:338-342

Noueiry, A. O., and Ahlquist, P. 2003. Brome mosaic virus RNA replication: Revealing the role of the host in RNA virus replication. Annu. Rev. Phytopathol. 41:77-98.

O'Reilly, E. K., Paul, J. D., and Kao, C. C. 1997. Analysis of the interaction of viral RNA replication proteins by using the yeast two-hybrid assay. J. Virol. 71:7526-7532.

O'Reilly, E. K., Wang, Z., French, R., and Kao, C. C. 1998. Interactions between the structural domains of the RNA replication proteins of plant-infecting RNA viruses. J. Virol. 72:7160-7169.

Palukaitis, P., and García-Arenal, F. 2003. Cucumoviruses. Adv. Virus Res. 62:241-323

Quadt, R., and Jaspars, E. M. J. 1990. Purification and characterization of brome mosaic virus RNA-dependent RNA polymerase. Virology 178:189-194.

Qiu, W., Park, J.-W., and Scholthof, H. B. 2002. Tombusvirus P19-mediated suppression of virus-induced gene silencing is controlled by genetic and dosage features that influence pathogenicity. Mol. PlantMicrobe Interact. 15:269-280

Rao, A. L. N., and Grantham, G. L. 1996. Molecular studies on bromovirus capsid protein. II. Functional analysis of the amino-terminal arginine-rich motif and its role in encapsidation, movement, and pathology. Virology 226:294-305.

Ratcliff, F., Harrison, B. D., and Baulcombe, D. C. 1997. A similarity between viral defense and gene silencing in plants. Science 276:1558-1560. 
Ratcliff, F., Montserrat Martin-Hernandez, A., and Baulcombe, D. C. 2001. Tobacco rattle virus as a vector for analysis of gene function by silencing. Plant J. 25:237-245.

Restrepo-Hartwig, M., and Ahlquist, P. 1996. Brome mosaic virus helicase- and polymerase-like proteins colocalize on the endoplasmic reticulum at sites of viral RNA synthesis. J. Virol. 70:8908-8916.

Roossinck, M. J., and Palukaitis, P. 1990. Rapid induction and severity of symptoms in zucchini squash (Cucurbita pepo) map to RNA 1 of cucumber mosaic virus. Mol. Plant-Microbe Interact. 3:188-192.

Rouf Mian, M. A. R., Zwonitzer, J. C., Hopkins, A. A., Ding, X. S., and Nelson, R. S. 2005. Response of tall fescue genotypes to a new strain of Brome mosaic virus. Plant Dis. 89:224-227.

Ruiz, M. T., Voinnet, O., and Baulcombe, D. C. 1998. Initiation and maintenance of virus-induced gene silencing. Plant Cell 10:937-946.

Ryu, C. M., Anand, A., Kang, L., and Mysore, K. S. 2004. Agrodrench: A novel and effective agroinoculation method for virus induced silencing in roots and diverse Solanaceous species. Plant J. 40:322-331.

Sacher, R., and Ahlquist, P. 1989. Effects of deletion in the N-terminal base arm of brome mosaic virus coat protein on RNA packaging and systemic infection. J. Virol. 63:4545-4552.

Scofield, S. R., Huang, L., Brandt, A. S., and Gill, B. S. 2005. Development of a virus-induced gene-silencing system for hexaploid wheat and its use in functional analysis of the Lr21-mediated leaf rust resistance pathway. Plant Physiol. 138:2165-2173.

Slaymaker, D. H., Navarre, D. A., Clark, D., del Pozo, O., Martin, G. B. and Klessig, D. F. 2002. The tobacco salicylic acid-binding protein 3 (SABP3) is the chloroplast carbonic anhydrase, which exhibits antioxidant activity and plays a role in the hypersensitive defense response. Proc. Natl. Acad. Sci. U.S.A. 99:11640-11645.

Smith, N. A., Singh, S. P., Wang, M.-B., Stoutjesdijk, P. A., Green, A. G., and Waterhouse, P. M. 2000. Total silencing by intron-sliced hairpin RNAs. Nature 407:319-320

Tai, Y.-S., Bragg, J., and Edwards, M. C. 2005. Virus vector for gene silencing in wheat. Biotechniques 39:310-314.

Takeda, A., Nakamura, W., Sasaki, N. Goto, K., Kaido, M., Okuno, T., and
Mise K. 2005. Natural isolates of Brome mosaic virus with the ability to move from cell to cell independently of coat protein. J. Gen. Virol. 86:1201-1211

Takeshita, M., Suzuki, M., Kuwata, S., and Takanami, Y. 1998. Involvement of cucumber mosaic cucumovirus RNA2 and RNA3 in viral systemic spread in radish plant. Arch. Virol. 143:1109-1117.

Tao, X., and Zhou, X. 2004. A modified viral satellite DNA that suppresses gene expression in plants. Plant J. 38:850-860.

To, K.-Y., Suen, D.-F., and Chen, S.-C. G. 1999. Molecular characterization of ribulose-1,5-bisphosphate carboxylase/oxygenase activase in rice leaves. Planta 209:66-76.

Traynor, P., Young, B. M., and Ahlquist, P. 1991. Deletion analysis of brome mosaic virus 2a protein: Effects on RNA replication and systemic spread. J. Virol. 65:2807-2815.

Urbanowicz, A., Alejska, M., Formanowicz, P., Blazewicz, J., Figlerowicz, M., and Bujarski, J. J. 2005. Homologous crossovers among molecules of Brome mosaic bromovirus RNA1 or RNA2 segments in vivo. J. Virol. 79:5732-5742.

Voinnet, O. 2005. Induction and suppression of RNA silencing: Insights from viral infections. Nature Rev. Genet. 6:206-221.

Waterhouse, P. M., Graham, M. W., and Wang, M.-B. 1998. Virus resistance and gene silencing in plants can be induced by simultaneous expression of sense and antisense RNA. Proc. Natl. Acad. Sci. U.S.A 95:13959-13964.

Wojtkowiak, A., Siek, A., Alejska, M., Jarmolowski, A., SzweykowskaKulinska, Z., and Figlerowicz, M. 2002. RNAi and viral vectors as useful tools in the functional genomics of plants. Construction of BMVbased vectors for RNA delivery into plant cells. Cell. Mol. Biol. Lett. 7:511-522.

Wyatt, S. D., and Kuhn, C. W. 1980. Derivation of a new strain of cowpea chlorotic mottle virus from resistant cowpeas. J. Gen. Virol. 49:289296.

Zhang, C., and Ghabrial, S. A. 2006. Development of Bean pod mottle virus-based vectors for stable protein expression and sequence-specific virus-induced gene silencing in soybean. Virology 344:401-411. 